\title{
Economic Relations between Albania and France 1945-1990
}

\author{
Arshela Arapi \\ Ministry of Foreign Affairs, \\ Paris, France \\ Valentina Duka
}

Faculty of History and Philology,

Tirana University, Albania

Doi: 10.1515/ajis-2017-0023

\begin{abstract}
France had trade deals with several Balkan countries, which were often carried out by private firms that exchanged mutual interest. It would be of interest that even with Albania resumed exchanges for a category of articles despite the lack of a regular convention. Their purpose was to resume the works on kerosene requirements. This brought about the improvement of the Albanian economy and meeting the needs of the France for these products, which in turn strengthened even more the economic and political relations of the two countries. With the insistence of the French side, on August 1956, a trade agreement was signed between Albania and France, where the French Government allowed the exchange of goods between the two countries as a compensation to French firms seeking to collaborate with our country. It is worth pointing out that the trade relations that Albania had with France until 1964 was generally satisfactory. Albania's export and import plans were satisfactorily fulfilled and a better basis for new successes in forecasts and plans for the future in 1965 was provided. In the official talks with the French side in mid eighties, the Albanian side proposed the establishment of a joint group within the Chambers of Commerce to look at the possibilities of France purchasing our minerals and the possibilities of Albania buying their equipment. Based on the credits opened by French firms and our foreign trade enterprises, the release of the respective goods was followed in both directions. Thus, our companies have been releasing confectionery, towels, clothespins, chairs etc. French companies have continued to release electronic equipment, clay, oil spill delta and various exchange parts. Several other economic agreements were signed between two countries which increased the level of Albanian exports towards France.
\end{abstract}

Keywords: economy, agreement, oil assets, export

\section{Introduction}

During the first time period from 1926-1946 and 1946-1949 it was observed that the relations between these two countries were not so strong and well-developed. Albania was a small country and far from being developed and advanced (Fishta Iliaz \& Toçi Veniamin 1983). It had resources, but no opportunity for their exploitation, for instance: it had large mineral assets such as oil, copper, chrome and so on. In Albania there was a lack of information as well as a lack of opportunities to use these resources for themselves. In addition to the mineral resources, there was plenty of plant wealth, fertile land, aquatic resources that began to be sought after by other countries which had the opportunity to exploit them. There was hardly any information on their use, the necessary tools in archeology and the use of underground minerals. France, as a superpower, was interested in 
exploiting our assets, but we also had interest in a good cooperation with France which in turn would help us to advance in the field of foreign trade relations. There would be a mutual benefit. It was noted that the exports to France were higher in the period before the $30-\mathrm{s}$. This period belonged to King Zog and it symbolized a flourishing of the relations between Albania and France. However, due to the undeveloped economic status of Albania this relationship was not strengthened any further (Fishta lliaz \& Ziu Mihal 1999). This led to a decline in the exports from Albania to France. The purpose of this investigation is to feature the relations amongst Albania and France in the economic area.

\section{Material and Methods}

The study is based on Albanian and French archival sources with documents and diplomatic acts related to Albania. Unpublished archive resources are complemented by published documents, which for the subject of this study have not been abundant.

\section{Results}

In 1946 France proposed to Albania to carry out a trade exchange which involved Albania giving timber and leather to France and France, in exchange, would give Albania agricultural tools, perfumes, industrial articles etc (DDAMPJSH). In 1951 French Legation thought to extend the possibility of improving relations between Albania and France by showing an interest in the economic aid it would provide to poor families and children with health problems (Archive of Ministry of Foreign Affairs, Albania, 1954, d 177, p. 1).

This was an initiative which in itself depicted a significant improvement in Albanian-French relations. A monetary fund would already be set up and it would be available to the Albanian families in France. They would receive the necessary support whenever they were faced with various difficulties. The degree of profitability of these revenues would be determined by representatives of the French legation who would visit the families in which they would determine who would receive the assistance.

There was already interest not only for trade exchanges, but also for the use of income set up with the goal of helping each-other. The degree of cooperation began to increase, thus leading to an awareness-raising initiative for improving these relations.

In the second time period between 1951-1958 efforts were made by the Albanian side to create trade agreements between Albania and France, but the French side didn't seem to show any interest (Archive of Ministry of Foreign Affairs, Albania, 1957, d. 186, p. 53).

This, somehow, marked the importance of co-operation between both sides, but France was no longer interested in creating trade relations with us, and that was a bad thing for Albania. By the end of 1957, the French Government began to show interest in the development of trade relations with Albania, since at that time Albania started to be well-known for its major oil assets (Archive of Ministry of Foreign Affairs, Albania, 1960, d. 272, p. 10, 12). France was already interested in receiving the huge oil assets that would be profitable for the French state, but it should also be pointed out that we would also be interested in this particular cooperation because it would increase our country's revenue and the number of materials that would come from overseas. Later on, the export of the Albanian heather plant to France started as well, but we should also mention bitumen as an export product.

So we can say that trade relations between Albania and France began to grow stronger in this period. Different mineral products such as oil, natural bitumen, tobacco leaves, chrome ore etc. were exported to France.

Meanwhile, there were certain goods to be exported from France to Albania such as ferro concrete, steel, chrome ore, paper product etc. So the exchange would be made for those materials that would interest each party. It can be said that there was a noticeable improvement in trade relations between the two countries.

In the third time period, which dates back to 1956-1959, there was a further improvement with a special emphasis placed on trade exchange relations (Historia e Ekonomisë, 2004). It was 
observed that the status of trade exchanges was increasing, and France was increasingly seeking to obtain oil and mineral products. Furthermore, in 1961, a Trade Treaty was established as an opportunity to strengthen trade relations between Albania and France (Archive of Ministry of Foreign Affairs, Albania, 1961, d. 277, p. 38-44).

Regarding the other time period, it was noted that in 1962 the first trade and navigation agreement was already drafted in France and this was another sign of trade relations growing stronger (Griffith, W.E. 1963).

In the next period from 1973-1979, France's exports were at the same levels as in the beginning. Trade was minimal focusing only on agricultural products (Archive of Ministry of Foreign Affairs, Albania, 1974, d 317 p. 12). One of the reasons that led to a non-fulfillment of the plan for the exchange of goods was that Albania lacks in traditions for these types of exchanges. Albania has been an inexperienced country in the exchange of goods and this made it hard to adapt to the changes that came from other countries in business form. The Albanian exports to France were 20 million francs in 1976, while imports from France were about 21 million francs.

In the last time period from 1980-1986, there was a complication of trade relations between both countries. This was due to the fact that Albania was the only country in the world that was prohibited by its constitution to buy goods on credit and insisted on a trade based on a compensation system.

Table 1. An overview of the annual trade balance sheet between Albania and France.

\begin{tabular}{|c|c|c|c|}
\hline Year & Currency & Imports & Exports \\
\hline $1930-1932$ & Fr. ari & 700,000 & 50,000 \\
\hline 1956 & $\$$ & 400,000 & 700,000 \\
\hline 1963 & $\$$ & 460,000 & 651,000 \\
\hline 1964 & $\$$ & 610,000 & 968,840 \\
\hline 1965 & & $8,200,000$ & $8,100,000$ \\
\hline 1970 & Fr. ari & $19,000,000$ & $16,000,000$ \\
\hline 1976 & Fr. ari & $21,000,000$ & $20,000,000$ \\
\hline
\end{tabular}

Even during this period efforts were made to strengthen trade exchange relations eg. for obtaining Albania's minerals from the French side and for receiving the tools from the Albanian side. This led to a recovery of the situation for not completely destroying these relations, so there was opportunity to lead to a growth and strengthening these ties between Albania and France.

Albanian-French trade relations have always been complicated by the fact that Albania was the only country in the world prohibited by its own constitution to buy on credit and insisting on a trade based on compensation system. In 1980, the National Bank of Paris, one of Frances's most important banks with which Albania had a well-established relationship, proposed to the Albanian side to enter into an agreement for co-operating in the field of foreign trade. The National Bank of Paris agreed to collaborate on finding new firms interested in purchasing our export goods in France and other countries for those items we were interested in. The sales contracts would be made through commercial firms, without the intermediary of banks, although in those particular cases where there were difficulties, banks would help to overcome them as well as in the case of difficulties in the execution of contracts.

Then on May 25, 1984, trade talks were held between our delegation led by Mr. Pajtim Ajazi and the French delegation headed by the Director of Europe at the Ministry of Foreign Affairs, Francois Plezan.

The main way to minimize the export-import gap between both countries was to export the Albanian minerals to France, and in this context, it was achieved the conclusion of long-term contracts which in turn would ensure a continuation of trade between the two countries. Additionally, the export of our agricultural products to France, processed or unprocessed products, was another way to help minimize this imbalance.

Furthermore, on December 26, 1985 in the official talks with the French side during the visit of 
the Secretary of State for Foreign Affairs, Zh. M. Bajle, the Albanian side proposed the establishment of a joint group within the Chambers of Commerce to look at the possibilities of France purchasing our minerals and the possibilities of Albania buying their equipment.

Based on the credits opened by French firms and our foreign trade enterprises, the release of the respective goods was followed in both directions. Thus, our companies have been releasing confectionery, towels, clothespins, chairs etc (Raymond Zickel and Walter R. Iwaskiw, 1994). French companies have continued to release electronic equipment, clay, oil spill delta and various exchange parts.

\section{Conclusion}

There was some progress in the 20th century, but not enough to make Albania an economically advanced country compared to other nations in the region, let alone to Western European countries. From the 1920-s until mid-40-s, the economy was steered toward one direction and then another, depending on the foreign power exercising the greatest influence at the time. This did little to create a more productive economy, because it didn't help creating a better and more qualified working class, or a capable and qualified engineering and administrative personnel. The economy was mainly meant to provide raw materials and markets, with little industrial capability. This meant that the attempt of the communist regime that came to power after 1946 to turn Albania into a more industrial economy wasn't as successful as it could have been. The early decades went pretty well, as a centralized economy is usually more effective when focused on a given target. The industrial capability grew rapidly and impressively, but it was curtained by a lack of expertise, market and especially by the rigidity that such a system implies. The communist regime leaned on a string of other communist countries to provide markets and specialized assistance, but even this wasn't persistent (first Yugoslavia, then USSR, and then finally China). The economic relations with France were regarded as very important by the communist regime but Albania has been an inexperienced country in the exchange of goods and this made it hard to adapt to the changes that came from France in business form owing also to the fact that Albania was the only country in the world that was prohibited by its constitution to buy goods on credit and insisted on a trade based on a compensation system. To sum up, it can be concluded that trade relations have fluctuated from one period to the next, but they were not profoundly volatile.

\section{References}

Archive of Ministry of Foreign Affairs, Albania, 1954, d 177, p. 1

Archive of Ministry of Foreign Affairs, Albania, 1957, d. 186, p. 53

Archive of Ministry of Foreign Affairs, Albania, 1960, d. 272, p. 10, 12

Archive of Ministry of Foreign Affairs, Albania, 1961, d. 277, p. 38-44

Archive of Ministry of Foreign Affairs, Albania, 1974, d 317 p. 12.

DDAMPJSH, Dosja Nr.38, xhaketa 284,viti 1946.

Fishta Iliaz \& Toçi Veniamin (1983) Gjendja ekonomike e Shqipërisë në vitet 1912-1944, prapambetja e saj, shkaqet dhe pasojat, botim i Institutit të Historisë së Akademisë së Shkencave, Tiranë.

Fishta Iliaz \& Ziu Mihal (1999) Ndërhyrja e kapitalit të huaj dhe roli i saj për pushtimin e Shqipërisë (1936-1939), Tiranë

Griffith, W.E. (1963) Albania and Sino-Soviet Rift, Cambridge, Massachusetts

Historia e ekonomisë së Shqipërisë 1944-1960, Tiranë, 2004.

Raymond Zickel and Walter R. Iwaskiw, editors. Albania: A Country Study. Washington: GPO for the Library of Congress, 1994. 